\title{
ANALISIS POSTMODERN NOVEL HUJAN BULAN JUNI KARYA SAPARDI DJOKO DAMONO
}

\author{
(A Postmodern Analysis on Hujan Bulan Juni \\ A Novel by Sapardi Djoko Damono)
}

\author{
Trisnawati \\ SMK Muhammadiyah Sampit \\ Jalan Merak 47A, Sampit, Kotawaringin Timur, Kalimantan Tengah \\ Pos-el: spdtrisnawati@gmail.com
}

(Naskah Diterima 30 Desember 2020_-Direvisi 2 Mei 2021—Disetujui 4 Mei 2021)

\begin{abstract}
The development of the era of the creation of literary works can not be separated from the paradigm of modernism. However, modernism is considered obsolete and incapable of meeting human needs anymore so by humans it must be replaced with a new paradigm. Protests against modernism spawned a new paradigm called postmodern. This study aims to describe aspects of eclecticism in Sapardi Djoko Damono's novel Hujan Bulan Juni in the postmodern paradigm based on the Lyotard theory. The study used a qualitative descriptive approach. The data analyzed in this study are unit of stories related to aspects of eclectisism, namely the blurring of borders between countries, mixing foreign cultures with local cultures, adoption of behavior and the use of goods originating from foreign countries.
\end{abstract}

Keywords: novels, postmodern, eclecticism

\begin{abstract}
Abstrak
Penciptaan karya sastra tidak lepas dari paradigma modernisme. Namun, modernisme dianggap usang dan tidak mampu memenuhi kebutuhan manusia lagi sehingga harus digantikan oleh paradigma baru. Protes terhadap modernisme melahirkan paradigma baru yang disebut postmodern. Penelitian ini bertujuan untuk mendeskripsikan aspek eklektisisme dalam novel Hujan Bulan Juni karya Sapardi Djoko Damono dalam paradigma postmodern berdasarkan teori Lyotard. Penelitian ini menggunakan pendekatan deskriptif kualitatif. Data yang dianalisis dalam penelitian ini berupa satuan cerita yang berkaitan dengan aspek eklektisisme berupa pengaburan batas antarnegara, pencampuran budaya asing dengan budaya lokal, pengadopsian perilaku, dan penggunaan barang-barang yang berasal dari negara asing.
\end{abstract}

Kata kunci: novel, postmodern, eklektisisme

\section{PENDAHULUAN}

Sastra merupakan cerminan fenomena atau gejala sosial di sekitarnya. Karya sastra dianggap sebagai tempat yang bersifat sosial untuk menyuarakan pandangan terhadap dunia pengarangnya yang berupa gagasan, aspirasi, dan perasaan. Hal itu menunjukkan bahwa sastra juga merupakan suatu proses berpikir yang dituangkan ke dalam bahasa. Nurgiyantoro menyatakan bahwa fiksi, juga karya sastra pada umumnya, merupakan karya baru yang 
menampilkan dunia dalam bentuk kata dan bersifat berdiri sendiri (Nurgiyantoro, 2010).

Karya sastra yang lahir dari proses berpikir tentu saja tidak terlepas dari dorongan mendasar atau pokok kodrat insaniah seseorang sebagai manusia, yaitu untuk mengaktualisasikan diri dan memberikan perhatian pada realitas kehidupan serta pada dunia khayalan yang dianggap nyata (Faisal, 2010).

Seiring dengan perkembangan zaman, proses penciptaan karya sastra tentu tidak dapat dilepaskan dari paradigma modernisme, khususnya dalam bidang seni dan kebudayaan. Namun, ketidakpuasan manusia dan ketidakmampuannya bertahan dari kemajuan teknologi, kapitalis, serta cara berpikir modern membuat mereka menganggap modernisme terlalu mematok sesuai dengan konvensikonvensinya sendiri. Modernisme dianggap telah usang dan tidak mampu menjawab kebutuhan manusia secara utuh sehingga harus diganti dengan paradigma baru, yaitu postmodernisme.

Hermawan menyatakan bahwa postmodernisme dikaitkan dengan segala sesuatu yang mengalami ketidaksinambungan (discontinuity), perombakan (disruption), pergeseran (dislocation), peminggiran (decenting), ketidakpastian (indeterminacy), dan antitotalisasi (antitotalication). Postmodern dapat dikatakan merupakan peleburan segala bidang sehingga tidak ada lagi batasan-batasan yang membedakan antara budaya rendah dan budaya tinggi yang mana hal tersebut merupakan oposisi biner para kaum modernis (Hermawan, 2016).

Sri (2019) mengatakan bahwa postmodern menawarkan intertekstualitas suatu karya yang juga menyimpan pengaburan batas antarnegara, menghilangkan batasan antara dunia seni dan kehidupan seharihari, batasan antara dunia fiksi dan realitas, serta batas antara budaya adiluhung dan populer.

Perkembangan karya sastra, khususnya novel saat ini, semakin tidak terbatas. Di Indonesia paradigma postmodern dalam novel terus bermunculan. Puncak kehadiran paradigma postmodern di Indonesia ditandai dengan munculnya novel Saman karya Ayu Utami pada tahun 2000. Tidak heran jika sejumlah kritikus sastra menyebutkan bahwa Saman merupakan "pembaru" estetika modern (Dewi, 2017).

Kehadiran postmodern sebagai pembaruan terhadap paradigma modern dianggap membawa angin segar bagi kesusastraan Indonesia, khususnya novel. Secara khusus, penelitian ini mendeskripsikan paradigma postmodern dengan hanya berfokus pada aspek atau ciri eklektisisme yang terdapat di dalam novel.

Penelitian tentang postmodern memang telah banyak dilakukan, namun belum ada yang befokus pada eklektisisme. Penelitian terhadap novel Maryamah Karpov karya Andrea Hirata dilakukan oleh Faisal. Faisal menyatakan bahwa terdapat ciri-ciri postmodern dalam novel Maryamah Karpov, yaitu eklektisisme, parodi, ironi, dan pastiche yang ditinjau berdasarkan teori Jean Francois-Lyotard (Faisal, 2010).

Selain itu, Pujiharto meneliti struktur postmodern dalam novel sekuel Saman yang berjudul Larung karya Ayu Utami (Pujiharto, 2005). Menurut Pujiharto, novel Larung menunjukkan postmodern, yaitu struktur-struktur ontologis yang dikaji dengan teori McHale.

Dewi meneliti identitas budaya berdasarkan kajian teori postmodern dalam novel Kembar Keempat karya 
Sekar Ayu Purnama. Ia menemukan ciri postmodern berupa agama yang dianggap sebagai pembebas dan pembaru dalam cerita, pengelabuan identitas, penopengan, dan adopsi budaya (Dewi, 2017).

Jabrohim menyatakan bahwa sastra tidak bersifat otonom, tetapi terikat dengan situasi dan kondisi di mana karya itu diciptakan. Artinya, sebuah karya sastra yang diciptakan memang tidak serta-merta muncul begitu saja tanpa pengaruh-pengaruh luar, misalnya lingkungan budaya dan sosial (Jabrohim, 2005). Oleh sebab itu, Hermawan menyatakan bahwa konsep postmodern bukan hanya sebuah istilah yang digunakan untuk memberikan definisi dari sebuah gaya khusus (Hermawan, 2016). Namun, postmodern dikatakan sebagai penghubung yang berfungsi untuk memunculkan sebuah tatanan baru dalam kehidupan sosial. Jean FrancoisLyotard membedakan beberapa aspek penting yang dikaitkan dengan postmodern di bidang seni (Sarup, 2007), di antaranya yaitu

1. tidak ada lagi batasan antara dunia seni dan dunia kehidupan sehari-hari;

2. penghapusan perbedaan seni rendah dan seni tinggi, seni populer dan seni murni;

3. eklektisisme, yaitu pencampuran budaya;

4. parodi, yaitu tiruan dari teks masa lalu sebagai bentuk protes atau ungkapan ketidaksenangan berkaitan dengan intensitas karya masa lalu;

5. pastiche, yaitu tiruan dari budaya masa lalu yang diangkat pada masa sekarang sebagai bentuk apresiasi;

6. ironi, yaitu suatu kejadian yang bertentangan dengan keadaan sebenarnya;

7. kitsch, yaitu reproduksi gaya;

8. camp, yaitu pengelabuan identitas atau penopengan.
Dari beberapa aspek yang dikemukan Lyotard, fokus penelitian ini adalah aspek eklektisisme yang terdapat dalam novel Hujan Bulan Juni karya Sapardi Djoko Damono. Faisal menyebut bahwa eklektisisme dapat dipahami sebagai pencampuran budaya asing ke dalam kebudayaan sendiri (Faisal, 2010). Hal itu dapat terjadi di mana pun. Sebagai contoh, sarapan dengan roti dan selai atau meminum cocktail di sebuah pesta pernikahan merupakan adopsi budaya asing yang dapat dikatakan sebagai ciri eklektisisme.

Hatija menyatakan bahwa eklektisisme dapat dilihat dari kebiasaan tokoh yang memadukan atau mencampurkan kebudayaan asing ke dalam kebudayaan lokal. Selain itu, penggunaan bahasa, benda, arsitektur, atau aktivitas dari negara lain juga dapat dikatakan sebagai eklektisisme (Hatija, 2018).

Penelitian ini bertujuan untuk mendeskripsikan aspek eklektisisme berdasarkan teori postmodern Jean Francois-Lyotard dalam novel Hujan Bulan Juni karya Sapardi Djoko Damono. Jika penelitian terdahulu mendeskripsikan postmodern dengan keseluruhan aspek yang terdapat di dalamnya, penelitian ini hanya akan mendeskripsikan aspek eklektisismenya agar lebih spesifik dan terperinci. Penelitian ini diharapkan dapat menjadi acuan atau referensi bagi penelitian selanjutnya yang berkaitan dengan aspek-aspek lain postmodern.

\section{METODE PENELITIAN}

Penelitian ini menggunakan pendekatan deskriptif kualitatif. Sumber data penelitian adalah novel Hujan Bulan Juni karya Sapardi Djoko Damono. Data berupa alur cerita yang berkaitan erat dengan aspek eklektisisme postmodern. Adapun teknik 
pengumpulan data dalam penelitian ini adalah teknik pustaka, yaitu dengan melakukan langkah-langkah membaca novel Hujan Bulan Juni, mengidentifikasi, dan memberikan tanda hanya terhadap aspek eklektisisme. Adapun teknik analisis data yang digunakan adalah interpretasi dan penyimpulan.

\section{PEMBAHASAN}

Eklektisisme dalam novel Hujan Bulan Juni terlihat dari kebiasaan tokoh yang mencampurkan kebudayaan asing dengan kebudayaan bangsanya. Tidak hanya itu, pencampuran budaya yang dimaksud dalam hal ini dapat juga berupa menonton acara televisi dari bangsa lain, seperti dalam kutipan berikut.

Ketika pertama kali mengenalnya di rumah Toar Pelenkahu, temannya SMA, Sarwono langsung merasa dirinya menjadi tokoh utama sebuah sinetron dan adik Toar itu dalam otaknya sempat muncul sebagai Audrey Hepburn atau Grace Kelly-tapi jelas bukan Mak Wok. Ketika menjelaskan nama-nama itu kepada Pingkan, jawabannya yang didengarnya malah ejekan. Yaah, ketahuan deh umurmu. Sarwono tidak menjawab. Ia kenal nama-nama itu dari ibunya, yang katanya sejak kecil suka nonton film hollywood (Damono, 2015:11).

Perilaku tokoh yang suka menonton film Hollywood dalam kutipan tersebut merupakan aspek eklektisisme. Kutipan tersebut jelas mendeskripsikan bahwa tokoh terbiasa menonton film Hollywood sehingga dapat mengingat nama tokoh utama dalam film tersebut. Hal itu menunjukkan tidak ada pembatasan negara dalam budaya menonton acara televisi, misalnya ketika berada di Indonesia harus menonton acara televisi yang berasal dari Indonesia.

Selain pencampuran budaya yang ditunjukkan dengan kebiasaan tokoh menonton film Hollywood di tengah bangsanya sendiri, pencampuran budaya juga ditunjukkan dengan menyukai halhal yang berada di negara lain, seperti ditunjukkan dalam kutipan berikut.

Ia pernah sekali ke Jepang, untuk ikut seminar budaya urban, dan rekannya dari universitas Tokyo waktu itu memberitahu bahwa dulu ada istilah hepubarnu stairu. Ketika ia bertanya apa itu, jawabnya itu hepburn style. Segera waktu itu ia ingat istilah Jepang dirai kiriningu untuk dry cleaning. Ia suka Jepang. Ia suka vokal akhir ' $u$ ' yang diucapkan orang Jepang, tidak peduli sedang berbicara apa. Ia suka bunga sakura yang hanya mekar seminggu di awal musim semi, dan langsung gugur bagaikan ronin yang dipenggal kepalanya oleh samurai yang dikhianatinya (Damono, 2015:11-12).

Selain tokoh menyukai hal-hal yang berhubungan dengan Jepang, ciri eklektisisme juga ditunjukkan dengan penggunaan bahasa asing (Inggris) yang digunakan di Jepang. Pengetahuan tokoh tentang sejarah ronin juga merupakan eklektisisme yang mengaburkan batasan antarnegara tersebut. Bahwa tidak ada batasan negara untuk mengetahui atau menyukai hal-hal yang berada di negara lain.

Aspek eklektisisme berupa pencampuran budaya juga terlihat dari penggunaan bahasa asing yang digunakan di negaranya sendiri, seperti dalam kutipan berikut.

Sarwono langsung ingat, waktu itu Pingkan diminta menjadi pendamping dalam sidang terbuka Ahmad, yang mendapat nilai cum-laude. 
"Yes, yes, yes! Jadi, kamu mau nganter aku?"

"Kamu memangnya masih perlu pembantu?"

"Well, jadi kamu mau," kata Sarwono langsung membantu membuat kesimpulan (Damono, 2015:28).

Penggunaan bahasa Inggris yes dan well dalam kutipan tersebut merupakan pencampuran budaya, yaitu menggunakan bahasa Inggris tidak harus di Inggris, di Indonesia pun boleh. Penggunaan bahasa asing dalam kutipan tersebut termasuk aspek eklektisisme.

Aspek eklektisisme lainnya adalah budaya mendengarkan lagu-lagu barat di negaranya sendiri, seperti dalam kutipan berikut.

Ia tahu benar, lelaki muda kurus yang bersandar dan disandarinya badannya itu tidak lain tidak bukan adalah setan jazz, terutama sumbernya adalah karya para maestro musik klasik seperti Beethoven, Chopin, Debussy, dan Bach (Damono, 2015:32-33).

Kutipan tersebut menunjukkan bahwa tokoh menyukai musik-musik barat meskipun orang Indonesia. Hal itu diperkuat lagi oleh kutipan berikut.

Pingkan suka musik juga, itu yang antara lain mendekatnya pertama kali ke Sarwono, lelaki muda yang suka ngoceh tentang musik jazz. Namun kesukaan Pingkan pada musik tidak sampai pada taraf menghabiskan uang jajannya untuk membeli CD impormeskipun ia juga sama sekali tidak pernah membuang uang hanya supaya bisa membeli $C D$ enam ribuan sekeping (Damono, 2015:33).

Kebiasaan tokoh Sarwono yang suka mendengarkan musik jazz mendorongnya membeli $\mathrm{CD}$ impor. Membeli CD yang berasal dari negara lain juga merupakan aspek eklektisisme, yaitu memakai barang-barang yang berasal dari negara lain berupa CD impor. Penggunaan barang yang berasal dari negara asing juga terdapat dalam kutipan berikut.

Pingkan segera menghentikan omong sekenanya itu dan minta Sarwono menyentuh-nyentuh ipad-nya mencari musik. Ketika mendengar suara gitar John Williams memainkan "Concierto de Aranjuez”, keduanya sepenuhnya diam mendengarkan, Pingkan mencium rambut Sarwono dan lakilaki muda yang mulai merasa cabut ke Langit Ketujuh itu merapatkan tubuhnya. Ia mulai merasakan getar gitir bersijingkat keluar-masuk tubuh mereka bergantian, menjahitnya menjadi satu (Damono, 2015:35-36).

Aspek eklektisisme yang ditunjukkan dalam kutipan tersebut tidak hanya penggunaan iPad, tetapi juga kebiasaan para tokoh tersebut dalam mendengarkan musik Barat. Tampak para tokoh menikmati musik asing yang berasal dari Australia. Berikut kutipankutipan yang menunjukkan aspek eklektisisme dengan ciri mendengarkan lagu Barat.

Pingkan sebenarnya lebih menyukai tafsir lagu itu oleh Charlie Byrd, tetapi pernah Sarwono bilang itu bukan klasik, itu jazz atau latin. Dan kalau Pingkan bilang, Lho, katanya suka jazz? Sarwono menjawab enteng, tapi, Concierto Williams seratus kali lebih jazz dari jazz, meskipun klasik, tetapi latin. Kalau sudah sampai taraf ocehan yang membingungkan dan susah ditelusuri juntrungnya itu, Pingkan memilih diam sebab ia juga merasa denting gitar Williams memang tafsiran yang tak tertandingi atas karya Joaquin Rodrigo itu (Damono, 2015:36).

Kebiasaan tokoh yang suka mendengarkan musik Barat sampaisampai menjadi perdebatan. Hal itu 
menunjukkan

pencampuran

mendengarkan negaranya sendiri. Begitu juga yang ditunjukkan oleh kutipan berikut.

\begin{abstract}
"Di sini," kata Sarwono sambil menepuk ipad pemberian pamannya yang punya bisnis furnitur, "ada Paco De Lucia, Pepe Romero, dan bahkan Joaquin Rodrigo sendiri, tetapi bagiku sentuhan jari-jari Williams mewakili siutan angin firdaus." Berkata demikian mata Sarwono seperti memandang langit yang kata puisi tidak ada batasnya, yang kata puisi wajahnya biru selalu bercermin pada laut (Damono, 2015:36).
\end{abstract}

Aspek eklektisisme lainnya ditunjukkan oleh budaya sarapan yang biasa dilakukan oleh negara Barat yang diadopsi oleh tokoh dalam novel. Hal itu tampak dalam kutipan berikut.

Mereka ternyata tidak bangun siang
dan sudah berada di ruang makan
untuk sarapan ketika Pak Ahmad
mengirim sms bahwa sopirnya agak
telat menjemput ke hotel. Coco crunch,
susu, selai, mentega, kopi, jus apel,
dan omelet tak lain adalah bagian dari
ritual, atau menurut pingkan basa-basi
pagi, yang menyadarkan keduanya
bahwa sudah waktunya untuk masuk
kembali ke ruang yang di setiap
denting sendok dan garpu terdengar
teka-teki. Atau sampiran pantun yang
memerlukan isi. Atau intro jazz yang
tidak pernah usai sebab ditarik diam-
diam, tanpa terasa sama sekali, dari
sebuah sonata Chopin (Damono,
2015:46).

Kutipan tersebut menggambarkan para tokoh yang sarapan dengan menu persis seperti menu sarapan orang Barat. Selain itu, perpaduan khayalan tokoh yang menggambarkan seolah mendengar pantun dan jazz juga merupakan aspek eklektisisme pencampuran budaya. Menu sarapan merupakan aspek eklektisisme pengadopsian budaya barat ke dalam budaya pribumi sendiri. Berikut merupakan aspek eklektisisme yang ditunjukkan tokoh, yaitu kebiasaan menonton berita internasional di televisi. Pemakaian barang berupa televisi buatan negara lain pun juga termasuk aspek eklektisisme seperti ditunjukkan dalam kutipan berikut.

"Kamu suka nonton CNN, ya?" Benny
tidak juga menajwab, hanya menatap
sepupunya dengan sorot mata yang
sulit sekali ditebak ke mana maunya.
Namun, Benny yakin seyakin-yakinnya
bahwa Pingkan pasti memahami
maksudnya. Sejak pertama biacara,
aku tahu ia anak cerdas, katanya
kepada diri sendiri. Seperti
diperintahkan oleh tenaga gaib yang
tidak akan mereka pahami, keduanya
bersama membayangkan adegan-
adegan yang selalu dan selalu muncul
di media ketika menyiarkan apa yang
mereka beri label berita internasional.
Seperti tidak ada pernah sisi
membahagiakan dalam kehidupan
orang-orang baik yang menghuni
negeri-negeri yang mereka sebut
Timur Tengah yang dalam
kenyataannya berada di sebelah barat
negeri ini seperti halnya India dan
negeri-negeri Eropa (Damono,
2015:48).

Penggunaan televisi atau menonton berita internasional merupakan aspek eklektisisme. Aspek eklektisisme menggunakan barang dari negara lain juga terdapat dalam kutipan berikut.

"He, sar, ilmu gituan untuk apa pula? Apa gunanya?” kata Pingkan seperti serius.

"Lha, ilmu kamu tentang musashi itu, untuk apa coba?"

"Tanpa musashi, apa kamu bisa naik Honda? Hahha." Pingkan selalu mengejek dosen muda itu karena 
masih saja naik sepeda motor kalau ngajar.

"Halo, Musashi yang suka minum coca cola."

"Hahaha, kamu ini kalau nenggak sake segelas kecil aja sudah pasti puyeng, Sar." (Damono, 2015:52)

Honda merupakan kendaraan buatan Jepang, tetapi digunakan oleh tokoh di negaranya, yaitu Indonesia. Begitu juga dengan minuman Coca Cola yang berasal dari Amerika, tetapi diminum di negaranya sendiri. Selain tidak adanya batas negara yang berkaitan dengan penggunaan barang dari negara asing dan meminum minuman yang berasal dari negara asing pula, kebiasaan meminum sake juga bukan budaya orang Indonesia, namun diadopsi di dalam kutipan ini. Aspek eklektisisme juga tergambar dalam kutipan-kutipan berikut.

Di rumah tantenya pun meja makan memiliki tugas serupa, menyediakan diri sebagai arena pementasa lisan kisah-kisah klasik yang tidak ditemuinya di televisi tetapi tetap saja menjadi bagian cara berpikir orangorang sehari-harinya terbujuk nonton televisi (Damono, 2015:58).

Kutipan berikut ini menggambarkan aspek eklektisisme menggunakan barang-barang dari negara lain.

Baterai samsung-nya habis. Lupa menaruh charger-nya di mana, Sarwono memutuskan untuk tidur saja. Yen arep modar ya modaro, katanya memelototi hp-nya (Damono, 2015:113).

Telepon genggam Samsung merupakan telepon genggam buatan Korea. Kutipan tersebut menunjukkan aspek eklektisisme berupa penggunaan barang dari negara asing.
Penggunaan aplikasi dari negara asing, yaitu Whatsapp, tergambar dalam kutipan ketika tokoh Sarwono mengirim pesan WA kepada Pingkan seperti dalam kutipan-kutipan berikut.

Silang menyilang WA antara Sarwono dan Pingkan pendek-pendek, keduanya kelelahan (Damono, 2015:62).

Sarwono manggut-manggut karena tidak tahu harus lapor apa lagi. Ia heran, tumben ayahnya ngomongnya genah. Ia mencabut selulernya dari saku, ternyata ada WA dari Pingkan; ada gambarnya nyengir di kereta. Di kamar, Sarwono membalas WA itu dengan selfie yang merekam tampangnya dengan dagu bertelekan kepalan tangannya: wajahnya serius, Pingkan menjawab, garing banget, Sar (Damono, 2015:90).

Aspek eklektisisme berupa penghapusan batas antarnegara dalam menikmati seni, seperti mendengarkan lagu-lagu Barat di negaranya sendiri juga tergambar dalam kutipan berikut.

Ia juga merindukan ayahnya yang telah mendidikanya mencintai musik klasik. Palenkahu sejak muda suka mengumpulkan lagu-lagu klasik yang direkam di piringan hitam, kaset, dan $C D$. Dari Sarwono ia kemudian mendengarkan lagu-lagu jazz yang bersumber komposisi musik klasik (Damono, 2015:59).

Pencampuran budaya juga terlihat pada kutipan berikut ketika tokoh membayangkan musik daerahnya seperti sejajar dengan musik klasik yang pernah didengarnya.

Ketika pertama kali mendengarkan Le Carnaval des Animaux, jauh sesudah ia dihajar oleh suara gamelan, ia tangkap bagian-bagian karya klasik itu seperti sejajar dengan tata krama krawitan yang dipahaminya (Damono, 2015:60). 
Aspek eklektisisme yang berkaitan dengan penggabungan budaya, yaitu penggunaan arsitektur dari Eropa, tergambar dalam kutipan berikut.

Di rumah Pingkan, Benny
mengungkapkan pertanyaan yang
mengganjal sejak tadi di keraton. Ada
gamelan lengkap, bentuk bangunan
utamanya pun rumah Jawa, yang
katanya sudah ada sejak zaman
Majapahit. Tetapi tiang-tiang dan
patung-patung yang bertebaran di
sana jelas tidak ada kaitannya dengan
Majapahit. Semua patung didatangkan
dari Eropa, juga tentunya cara
mengatur ruang-ruang dan kamar
(Damono, 2015:79).

Adanya penggabungan arsitektur dari Eropa dan Jawa seperti tergambar dalam kutipan tersebut merupakan aspek eklektisisme. Aspek eklektisisme tidak ada batasan antarnegara tergambar dalam kutipan yang menunjukkan bahwa di Jakarta pun ada penjual burger. Seperti diketahui, burger bukanlah makanan yang berasal dari Indonesia, tetapi dari Barat.

... Jakarta itu pedagang keliling burger yang menyulap fiir elise menjadi ikon oditorinya... (Damono: 2015:124).

Berdasarkan uraian tersebut, terlihat bahwa novel Hujan Bulan Juni memiliki paradigma postmodern yang dapat ditinjau berdasarkan aspek eklektisisme. Data tersebut juga membuktikan bahwa postmodern berperan penting dalam kemajuan penciptaan sebuah karya sastra. Novel tersebut menunjukkan bahwa suatu karya sastra semestinya mengikuti perkembangan zamannya.

Hasil penelitian menunjukkan bahwa terdapat aspek eklektisisme dalam novel Hujan Bulan Juni karya Sapardi Djoko Damono. Aspek eklektisisme yang ditemukan di dalam novel tersebut meliputi pencampuran budaya asing ke budaya lokal, pengadopsian perilaku/budaya asing yang dilakukan di negaranya, penggunaan barang-barang dan arsitektur yang berasal dari negara asing, dan penghapusan batas negara dalam menikmati seni.

\section{PENUTUP}

Lahirnya postmodern yang tidak memisahkan sastra modern dari sastra adiluhung tentu saja membawa angin segar bagi perkembangan sastra, khususnya novel. Seiring dengan perkembangan zaman, novel pun juga berkembang secara dinamis.

Postmodern telah banyak memengaruhi penciptaan suatu karya, termasuk novel. Aspek eklektisisme merupakan salah satu aspek yang dapat dikaji dalam sebuah novel berdasarkan teori postmodern. Aspek eklektisisme dapat dicermati dari adanya percampuran kebudayaan bangsa asing dengan kebudayaan bangsa sendiri. Selain itu, aspek eklektisisme juga dapat dilihat dari pengadopsian perilaku, penggunaan barang-barang dan arsitektur dari negara asing, dan penghapusan batas dalam menikmati seni negara asing.

Selain eklektisisme, novel Hujan Bulan Juni karya Sapardi Djoko Damono juga dapat diteliti berdasarkan teori postmodern dari aspek gaya bahasa. Hal itu ditandai oleh penggunaan bahasa-bahasa asing seperti Inggris dan Jepang dalam dialog tokoh.

\section{DAFTAR PUSTAKA}

Damono, S. D. (2015). Hujan Bulan Juni. Jakarta: Kompas Gramedia.

Dewi, N. F. (2017). Identitas Budaya dalam Novel Kembar Keempat 
Karya Sekar Ayu Asmara: Kajian Postmodern. Academica, 1(1), 8293.

Faisal, R. (2010). Kajian Postmodern pada Novel "Maryamah Karpov" Karya Andrea Hirata. Artikulasi, 7(7), 396-414.

Hatija. (2018). Representasi Postmodern Dalam Novel Supernova Edisi Petir Karya Dee Lestari: Tinjauan Sosiologi Postmodern Jean Francois Lyotard. E-Print UNM, 1, 1-20.

Hermawan, S. (2016). Teori Sastra. Banjarbaru: Scripta Cendekia.

Jabrohim. (2005). Teori Penelitian Sastra. Yogyakarta: Pustaka Pelajar.

Nurgiyantoro, B. (2010). Teori Pengkajian Fiksi. Yogyakarta: Gadjah Mada University Press.

Pujiharto. (2005). Konstruksi Postmodern dalam Novel Larung. Litera, 4, 88-97.

Sarup, M. (2007). Postrukturalisme dan Postmodern. Yogyakarta: Jendela. 